\title{
DETERMINANTY AKTYWNOŚCI STUDENTÓW W KONTEKŚCIE KSZTAŁCENIA E-LEARNINGOWEGO
}

\author{
Wioletta Sołtysiak \\ Akademia im. Jana Długosza w Częstochowie \\ Wydział Pedagogiczny
}

\begin{abstract}
Streszczenie: Celem opracowania jest identyfikacja determinant aktywności studentów w e-learningu. Dążąc do realizacji tak sformułowanego celu, przedstawiono aktywności na tle wybranych modeli komunikacyjnych, prezentowanych w literaturze przedmiotu oraz wykonanych wyników własnych, badań empirycznych. W tym kontekście dokonano rozpoznania sytuacji w zakresie włączania do procesu e-learningowego aktywności interpersonalnej uczestników kształcenia i ich wpływu na efekty nauczania-uczenia się. Zauważa się, że proces konstrukcji scenariuszy zajęć powinien uwzględniać różnego rodzaju interakcje komunikacyjne aktorów procesu kształcenia, które pozytywnie oddziałują na proces kształcenia e-learningowego.
\end{abstract}

Słowa kluczowe: aktywność interpersonalna, e-learning, kanały komunikacyjne, modele aktywności interpersonalnej

DOI: $10.17512 /$ znpcz.2016.3.1.15

\section{Wprowadzenie}

W obecnych czasach obserwuje się działania na różnych polach, które podlegają permanentnym zmianom. Rynek pracy nastawiony jest na eksplorację potencjalnych pracowników, posiadających określone umiejętności, wiedzę i kompetencje. Koniecznością stało się powiązanie edukacji z rynkiem pracy, stwarzanie przez system szkolnictwa możliwości, które pozwolą jednostce kreować ścieżkę edukacyjno-zawodową. Nasuwają się pytania: Jak skutecznie angażować studentów do samodzielności, do samokształcenia? Jak wyzwalać w uczącym takie cechy, jak: kreatywność, twórczość, komunikatywność, dynamizm działania? Jak kierować procesem nauczania, aby student osiągnął umiejętności działania pod presją czasu, a jednocześnie był odporny na stres i przygotowany do współpracy w grupie, rozproszonej geograficznie i wielokulturowej? Jak być niepokornym wobec nadmiarowości zasobów informacji i wiedzy, stawiając wysoko porzeczkę, być otwartym na zmianę dnia przyszłego?

Wobec szeregu pytań, które pojawiają się na drodze otwartego, zaangażowanego studenta, występuje edukacja, sprzyjająca ustawicznemu kształceniu.

W szkolnictwie wyższym dominującą formą nauczania - uczenia się jest forma tradycyjna, wymagająca fizycznej obecności nauczyciela i studenta w murach 
uczelni. Inną formą organizacji procesu kształcenia, powstałą $\mathrm{w}$ odpowiedzi na rozwój nowych technologii, jest edukacja z wykorzystaniem sieci internetowej, edukacja e-learningowa. Edukacja ta pozwala na swobodny wybór tempa i czasu nauki, sprzyja personalizacji kształcenia, lecz wymaga większej samodyscypliny. W tym kontekście wydaje się konieczne konstruowanie scenariuszy zajęć, opartych na zaangażowaniu studentów w tworzenie sieci powiązań między uczestnikami kształcenia, wyzwalaniu komunikacji interpersonalnej oraz pobudzanie do samodyscypliny.

Głównymi przesłankami, które skłaniają do podjęcia tematu, jest zwrócenie uwagi na determinanty aktywności studentów i ich rolę $\mathrm{w}$ procesie kształcenia, $\mathrm{z}$ wykorzystaniem platform do nauczania - uczenia się e-learningowego. W tym celu odniesiono się do działań w obszarze konstrukcji wartościowych kursów e-learningowych, z uwzględnieniem czynnika aktywności studentów. Pod pojęciem „wartościowe” rozumie się poprawność metodologiczną oraz pozytywne wpływanie na efekty kształcenia i satysfakcję studenta $\mathrm{z}$ kształcenia e-learningowego. Natomiast „aktywność studentów” będzie rozpatrywana w odniesieniu do przejawów interakcji i komunikacji interpersonalnej między uczestnikami procesu kształcenia z wykorzystaniem internetowych instrumentów interakcji.

Artykuł skierowany jest do nauczycieli zajmujących się konstrukcją scenariuszy zajęć na platformy e-learningowe oraz metodyków, którzy mają wpływ na dobór narzędzi komunikacyjnych, w relacjach uczestnik - uczestnik procesu kształcenia.

We wstępie nakreślono rolę kształcenia ustawicznego i wpisujący się $\mathrm{w}$ ten trend e-learning. W kolejnym podrozdziale przedstawiono modele aktywności studentów w ujęciu wielu autorów. Zwrócono uwagę na walory edukacyjne aktywności studentów z wykorzystaniem narzędzi do komunikacji. W następnym kroku odniesiono się do badań własnych autorki w zakresie determinant aktywności studentów z kierunków ekonomicznych województwa śląskiego. W podsumowaniu określono implikacje dla praktyków oraz wskazano kierunki dla dalszych badań.

\section{Modele aktywności studentów i ich rola w e-kształceniu}

Jak zauważa Iwona Mokwa-Tarnowska (Mokwa-Tarnowska 2014), dobrze skonstruowane programy kształcenia wszechmocnie stymulują studenta do różnych aktywności w czasie zajęć e-learningowych. W artykule skupiono uwagę na tych aktywnościach, które determinują sprzężenie zwrotne między uczestnikami kształcenia, komunikację w relacjach uczestnik-komputer, uczestnik-uczestnik.

W literaturze przedmiotu zauważa się wiele podejść do komunikacji w e-learningu. Jednym z nich jest podział ze względu na współpracę zespołową, w której występują dwie formy aktywności:

- realizowana z wykorzystaniem interaktywności,

- współocenianie studentów.

Aktywność studentów wykorzystująca interaktywność e-learningu odnosi się do komunikacji interpersonalnej przy pomocy takich narzędzi, jak: czat, forum dyskusyjne, e-mail, wideokonferencja, blog lub wiki. Komunikacja za pomocą wskazanych instrumentów wzmacnia zaangażowanie w proces uczenia się, zwiększa mo- 
tywację do wykorzystywania narzędzi, a tym samym kontaktu, osłabia uczucie osamotnienia (Mokwa-Tarnowska 2014).

Natomiast współocenianie studentów wykorzystuje narzędzia platformy e-learningowej w węższym zakresie. Najczęściej są to: forum dyskusyjne lub (i) wiki, lecz nie upraszcza to roli, jaką pełni w procesie kształcenia. Współocenianie przez innych studentów zmusza uczącego do wnikliwej analizy ocenianej treści i przemyślanej wypowiedzi, motywując do samokształcenia.

Anna Wach-Kąkolewicz (Wach-Kąkolewicz 2007) wyróżniła dwa opozycyjne modele edukacyjne w podejściu nauczycieli i studentów do aktywności e-learningowej:

- W centrum uwagi znajdują się treści edukacyjne.

- Na pierwszym miejscu jest aktywność poznawcza studenta.

Pierwszy model reprezentuje podający tok nauczania, wywodzi się z koncepcji behawioralnej, według której nauczyciel wskazuje, inicjuje i przeprowadza przez cały tok nauczania - uczenia się. Drugi model wywodzi się z paradygmatu konstruktywistycznego (zauważa się, że teoria konstruktywistyczna położyła podwaliny pod kształcenie e-learningowe, zob.: Bołtuć 2011), mającego w swoim założeniu samokształcenie i interakcję między głównymi aktorami procesu kształcenia. Uczący się wykorzystuje dostępne zasoby wiedzy udostępnione w ramach kursu oraz eksplorowane zasoby z sieci internetowej. Student dokonuje ich selekcji, tworzy nowe zasoby wiedzy we współkooperacji z innymi uczestnikami zajęć, sporządza własne komunikaty medialne, wykorzystując narzędzia platformy: poczta elektroniczna, fora dyskusyjne, komunikatory oraz inne służące interakcji.

Rita-Marie Conrad (nauczyciel, trener i wieloletni projektant kursów e-learningowych, zob. Conrad, Donaldson 2004) wypracowała model kursu online polegający na zamianie ról nauczycieli i studentów. Wyróżniła cztery fazy struktury logicznej kursu, determinujące role aktorów kształcenia i adekwatny dobór ich aktywności e-learningowej. Nazwy faz odzwierciedlają kreację modelu, zmierzającą do przejmowania odpowiedzialności studentów za proces kształcenia (Zając 2009):

- wprowadzenie - tworzenie społeczności uczących się (nauczyciel stymuluje tworzenie społeczności, aktywność uczestników ma służyć poznaniu w celu wytworzenia atmosfery współpracy);

- budowanie współpracy (student-współpracownik, nauczyciel-inicjujący aktywność, działania w kooperacji, współocenianie, dyskusja, konstruktywna krytyka);

- współpraca w grupie (zamiana ról, większy nacisk na samokształcenie studenta, swoboda w doborze metod i form kształcenia; nauczyciel-koordynator);

- partnerstwo w grupie (wzmocnienie samodzielności, wyłanianie liderów, moderowanie pracy grupy, współtworzenie treści dydaktycznych ${ }^{1}$, sprzyjanie rozwijaniu samodzielności i kreatywności).

\footnotetext{
1 „Współtworzenie treści dydaktycznych” dotychczas odbywało się najczęściej w formie tworzenia i rozbudowy haseł w Wikipedii lub tworzeniu wiki na potrzeby zajęć.
} 
$\mathrm{W}$ prezentowanym modelu zauważa się, iż student staje się partnerem w nauczaniu - uczeniu się, a nawet przejmującym aktywność edukacyjną, sprzyjającą tworzeniu nowej wiedzy.

W odniesieniu do modelu R.M. Conrad zauważa się podobne modele tworzone na potrzeby współpracy w organizacjach. D.K. Carr, K.J. Hard i W.J. Trahant prezentują interesujące podejście do tworzenia aktywnych grup. Wskazują na zachowania, których autorka nie ujęła, a przypuszcza się, że mogą predysponować do występowania w grupach dydaktycznych, ze względu na zróżnicowanie współuczestników (w zależności od płci, wieku, przekonań i in.). Autorzy zauważają, analogicznie jak R.M. Conrad, że aktywny zespół musi przejść przez minimum cztery fazy (Pyszka 2015, s. 38, cyt. za: Carr, Hard, Trahant 1998, s. 56-57):

- zapoznanie,

- pierwsze konflikty,

- wspólne uzgadnianie strategii i środków,

- współpraca.

Zwraca się uwagę na fazę „pierwsze konflikty”, burzliwość, którą w grupie o zróżnicowanej strukturze wewnętrznej nietrudno wywołać. Zauważa się, że grupy niehomogeniczne korzystnie oddziałują na efektywność pracy zespołu (zróżnicowanie pod względem posiadanej wiedzy, umiejętności, predyspozycje i in.) (Hackman 2002, s. 115). Natomiast cechy demograficzne, takie jak: wiek, płeć, narodowość, nie powodują istotnych różnic, w odniesieniu do tworzenia grup niehomogenicznych (Hackman 2002).

Inną ważną przesłanką, którą przypuszcza się, iż warto zastosować w przypadku tworzenia aktywnych społeczności studenckich, w ramach kształcenia e-learningowego, jest ingerencja $\mathrm{w}$ pracę zespołu. Wspomniani autorzy dowodzą, iż nie zawsze „pozytywna interwencja” prowadzi do uzyskania oczekiwanych rezultatów grupy. Dlatego moderując proces nauczania - uczenia się, nauczyciel musi pełnić rolę wnikliwego obserwatora, aby dostrzegając potencjał grupy, cechy poszczególnych uczestników, postawy i zachowania, odpowiednio dobierał i komunikował informację dotyczącą oczekiwań grupy.

\section{Aktywność studentów w e-learningu w świetle badań własnych}

Według opinii wielu autorów (Jelonek 2014, s. 276; Jędryczkowski 2013, s. 14, 16; Jędryczkowski 2012; Mokwa-Tarnowska 2014; Sysło 2009, s. 25) interakcja z wykorzystaniem kanałów komunikacyjnych, spersonalizowane przekazy informacji mogą sprzyjać współtworzeniu nowej wiedzy oraz poszerzaniu kompetencji. W odniesieniu do wymienionych aspektów aktywności studentów będą prowadzone dalsze rozważania.

Autorka w ramach badań własnych ${ }^{2}$ zajmowała się aktywnością studentów w odniesieniu do zajęć e-learningowych. W tym celu zastosowała metodę ankiety.

\footnotetext{
${ }^{2}$ Badania przeprowadzone na przełomie lutego i maja 2015 roku, w 7 szkołach wyższych województwa śląskiego, wśród studentów $\left(\mathrm{N}_{\text {studentów }}=270\right)$, kształcących na kierunkach o profilu ekonomicznym.
} 
Uporządkowany układ spisanych pytań i odpowiedzi skierowanych do nauczycieli akademickich utworzył kwestionariusz ankiety.

Zauważa się, że proces w e-learningu odbywa się za pomocą:

- komponentów platformy e-learningowej,

- portali społecznościowych,

- telefonii,

- spotkań tradycyjnych, na uczelni.

Na Rysunku 1 zobrazowano procentowy rozkład liczebności opinii studentów w odniesieniu do częstości wykorzystania instrumentów komunikacyjnych. Punktami zaznaczono najwyższe wskaźniki wykorzystania narzędzi komunikacyjnych. Opinie studentów odniesiono do interakcji w relacjach student-student oraz student-nauczyciel.

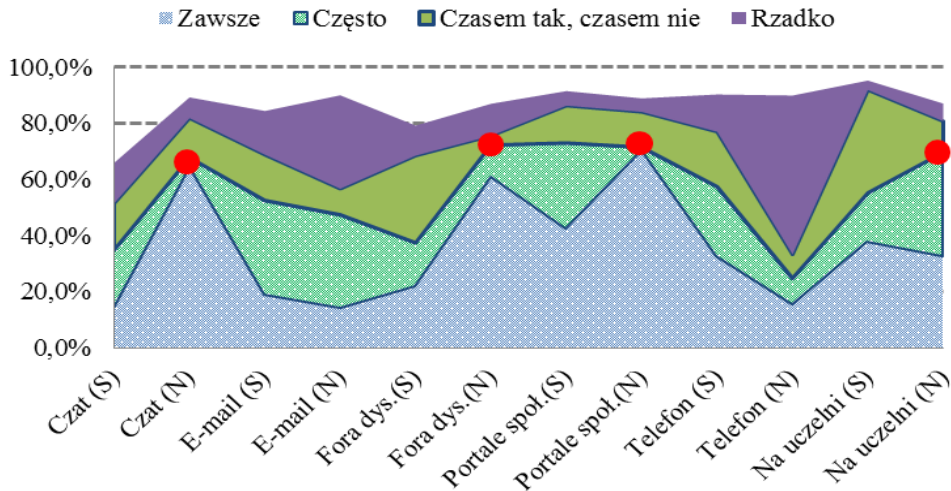

Litera S obok nazwy instrumentu komunikacyjnego informuje o relacjach student-student Litera $\mathrm{N}$ obok nazwy instrumentu komunikacyjnego informuje o relacjach student-nauczyciel

\section{Rysunek 1. Procentowy rozkład liczebności aktywności studentów z wykorzsta- niem instrumentów komunikacyjnych (w opinii studentów)}

Źródło: Opracowanie własne na podstawie wyników badań

Wyniki przeprowadzonych badań wskazują na największe nasilenie komunikacji wśród uczestników kształcenia z wykorzystaniem instrumentów:

- media społecznościowe w relacji student-student, wskaźnik częstości komunikacji $i^{3}$ wyniósł $73,0 \%$, natomiast $\mathrm{w}$ relacji student-nauczyciel wskaźnik interakcji wyniósł 71,5\%;

- na uczelni w relacji student-student, wskaźnik częstości komunikacji wyniósł $55,2 \%$, natomiast w relacji student-nauczyciel wskaźnik interakcji wyniósł $69,6 \%$;

- forum dyskusyjne w relacji student-student, wskaźnik częstości komunikacji wyniósł $37,4 \%$, natomiast $\mathrm{w}$ relacji student-nauczyciel wskaźnik interakcji wyniósł 72,6\%;

- czat w relacji student-student, wskaźnik częstości komunikacji wyniósł 34,8\%, natomiast w relacji student-nauczyciel wskaźnik interakcji wyniósł $67,7 \%$.

${ }^{3}$ Wskaźnik częstości komunikacji był liczony jako suma odpowiedzi respondentów „,zawsze” i „często”. 
W celu uszczegółowienia badań i potwierdzenia przypuszczeń, iż zmienne, takie jak: wiek, płeć oraz tryb studiów, mogą determinować różnice w podejściu do komunikacji interpersonalnej, sprawdzono występowanie istotnych różnic międzygrupowych. W tym celu wykorzystano test ANOVA rang Kruskala-Wallisa ${ }^{4}$ oraz ustalono poziomo istotności różnic między grupami na poziomie $\mathrm{p}<0,05$. W celu wykazania, z czego wynikają różnice międzygrupowe, wyliczono statystyki podstawowe, takie jak: medianę (Me), odchylenie ćwiartkowe (Q), średnią (M) i odchylenie standardowe (S). W Tabeli 1 pokazano rozkład częstości kanałów komunikacyjnych w relacji student-student w zależności od płci i wieku badanych.

Tabela 1. Rozkład częstości dotyczących kanałów komunikacyjnych w relacji student-student w zależności od płci i wieku badanych, w opinii studentów

\begin{tabular}{|c|c|c|c|c|c|c|c|c|c|c|c|c|c|}
\hline & \multirow{3}{*}{$\begin{array}{c}\text { Grupy } \\
\text { studenckie }\end{array}$} & \multicolumn{12}{|c|}{ Kanały komunikacyjne $w$ relacji student-student } \\
\hline & & \multicolumn{2}{|c|}{ czat } & \multicolumn{2}{|c|}{ e-mail } & \multicolumn{2}{|c|}{ fora dyskusyjne } & \multicolumn{2}{|c|}{$\begin{array}{c}\text { portale } \\
\text { spolecznościowe }\end{array}$} & \multicolumn{2}{|c|}{ telefonicznie } & \multicolumn{2}{|c|}{ na uczelni } \\
\hline & & $\mathbf{M e} \pm \mathbf{Q}$ & $\mathbf{M} \pm \mathbf{S}$ & $\mathbf{M e} \pm \mathbf{Q}$ & $\mathbf{M} \pm \mathbf{S}$ & $\mathbf{M e} \pm \mathbf{Q}$ & $\mathbf{M} \pm \mathbf{S}$ & $\mathbf{M e} \pm \mathbf{Q}$ & $\mathbf{M} \pm \mathbf{S}$ & $\mathbf{M e} \pm \mathbf{Q}$ & $\mathbf{M} \pm \mathbf{S}$ & $\mathrm{Me} \pm \mathbf{Q}$ & $\mathbf{M} \pm \mathbf{S}$ \\
\hline \multirow{4}{*}{$\frac{\mathscr{e}}{20}$} & \begin{tabular}{|l} 
kobiety \\
$\mathrm{N}=154$
\end{tabular} & $3,0 \pm 1,5$ & $2,6 \pm 1,5$ & $4,0 \pm 1,0$ & $3,4 \pm 1,3$ & $3,0 \pm 1,0$ & $3,1 \pm 1,4$ & $3,0 \pm 1,0$ & $3,9 \pm 1,2$ & $\begin{array}{c}4,0 \pm 1,0 \\
*\end{array}$ & $\begin{array}{c}3,7 \pm 1,3 \\
*\end{array}$ & $4,0 \pm 1,0$ & $3,9 \pm 1,0$ \\
\hline & $\begin{array}{l}\text { mężczyźni } \\
\mathrm{N}=116\end{array}$ & $3,0 \pm 1,5$ & $2,7 \pm 1,5$ & $3,0 \pm 1,0$ & $3,1 \pm 1,4$ & $3,0 \pm 1,0$ & $3,0 \pm 1,4$ & $3,0 \pm 1,0$ & $4,0 \pm 1,3$ & $\begin{array}{c}4,0 \pm 1,0 \\
*\end{array}$ & $\begin{array}{c}3,4 \pm 1,3 \\
*\end{array}$ & $4,0 \pm 1,0$ & $3,7 \pm 1,3$ \\
\hline & \begin{tabular}{|l} 
do 20 lat \\
$\mathrm{N}=57$
\end{tabular} & $\begin{array}{c}4,0 \pm 1,5 \\
*\end{array}$ & $\begin{array}{c}3,0 \pm 1,6 \\
*\end{array}$ & $\begin{array}{c}3,0 \pm 1,5 \\
*\end{array}$ & \begin{tabular}{|c|}
$3,0 \pm 1,3$ \\
$*$
\end{tabular} & $3,0 \pm 0,5$ & $3,3 \pm 1,3$ & $\begin{array}{c}4,0 \pm 0,5 \\
* \\
\end{array}$ & $\begin{array}{c}4,2 \pm 1,1 \\
*\end{array}$ & $3,0 \pm 1,0$ & $3,5 \pm 1,3$ & $4,0 \pm 1,0$ & $3,7 \pm 1,1$ \\
\hline & \begin{tabular}{|l|} 
od 21 do 25 \\
lat \\
$\mathrm{N}=161$
\end{tabular} & $\begin{array}{c}3,0 \pm 1,5 \\
*\end{array}$ & $\mid \begin{array}{c}2,7 \pm 1,5 \\
*\end{array}$ & $4,0 \pm 1,0$ & $3,2 \pm 1,4$ & $3,0 \pm 1,0$ & $3,0 \pm 1,5$ & $\begin{array}{c}4,0 \pm 0,5 \\
*\end{array}$ & $\begin{array}{c}4,1 \pm 1,2 \\
*\end{array}$ & $4,0 \pm 1,0$ & $3,7 \pm 1,3$ & $4,0 \pm 1,0$ & $3,9 \pm 1,1$ \\
\hline 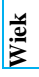 & $\begin{array}{l}\text { od 26 lat } \\
\mathrm{N}=52\end{array}$ & $\begin{array}{c}2,0 \pm 1,0 \\
*\end{array}$ & $\begin{array}{c}2,6 \pm 1,2 \\
*\end{array}$ & $\begin{array}{c}, 0 \pm 1,0 \\
*\end{array}$ & $\begin{array}{c}3,7 \pm 1,2 \\
*\end{array}$ & $3,0 \pm 1,0$ & $3,1 \pm 1,4$ & $\begin{array}{c}3,0 \pm 1,0 \\
*\end{array}$ & $\begin{array}{c}3,2 \pm 1,3 \\
*\end{array}$ & $4,0 \pm 0,5$ & $3,5 \pm 1,4$ & $4,0 \pm 1,0$ & $3,8 \pm 1,3$ \\
\hline \multicolumn{2}{|c|}{ Cala grupa } & $3,0 \pm 1,5$ & $2,7 \pm 1,5$ & $4,0 \pm 1,0$ & $3,3 \pm 1,4$ & $3,0 \pm 1,0$ & $3,1 \pm 1,4$ & $3,0 \pm 1,0$ & $3,9 \pm 1,2$ & $4,0 \pm 1,0$ & $3,6 \pm 1,3$ & $4,0 \pm 1,0$ & $3,8 \pm 1,1$ \\
\hline
\end{tabular}

Poziom istotności dla testu ANOVA rang Kruskala-Wallisa * $\mathrm{p}<0,05$

Źródło: Opracowanie własne na podstawie wyników badań

Zauważa się, iż w podejściu do kanałów komunikacyjnych zmienna płeć determinuje interakcje $\mathrm{w}$ relacjach student-student $\mathrm{w}$ odniesieniu do komunikacji z wykorzystaniem poczty e-mail oraz telefonicznej. W obu przypadkach kobiety częściej niż mężczyźni stosują wymienione instrumenty interakcji. Natomiast w odniesieniu do wieku badanych, studenci w wieku do 20 lat oraz od 21 do 25 lat częściej wykorzystują czat oraz portale społecznościowe do interakcji interpersonalnej niż studenci $\mathrm{w}$ wieku od 26 lat. Interesujące spostrzeżenia pojawiły się w przypadku różnic $\mathrm{w}$ wykorzystaniu poczty e-mail. Zauważa się, iż pokolenie najstarszych studentów, od 26 lat, zdecydowanie częściej korzysta z tej formy komunikacji niż pokolenie do 20 lat.

\footnotetext{
${ }^{4}$ Test ANOVA rang Kruskala-Wallisa stosuje się do zmiennych mierzonych na skali co najmniej porządkowej oraz nie wymaga normalności rozkładu zmiennych. Warunki zostały spełnione.
} 
W Tabeli 2 zademonstrowano rozkład częstości wykorzystania kanałów komunikacyjnych w relacji student-student w zależności od trybu studiów (w opinii studentów).

Tabela 2. Rozklad częstości opinii studentów dotyczących kanałów komunikacyjnych student-student w zależności od trybu studiów badanych

\begin{tabular}{|c|c|c|c|c|c|c|c|c|c|c|c|c|}
\hline \multirow{3}{*}{$\begin{array}{c}\text { Grupy } \\
\text { studenckie }\end{array}$} & \multicolumn{12}{|c|}{ Kanały komunikacyjne $w$ relacji student-student } \\
\hline & \multicolumn{2}{|c|}{ czat } & \multicolumn{2}{|c|}{ e-mail } & \multicolumn{2}{|c|}{ fora dyskusyjne } & \multicolumn{2}{|c|}{\begin{tabular}{|c|} 
portale \\
spolecznościowe
\end{tabular}} & \multicolumn{2}{|c|}{ telefonicznie } & \multicolumn{2}{|c|}{ na uczelni } \\
\hline & $\mathbf{M e} \pm \mathbf{Q}$ & $\mathbf{M} \pm \mathbf{S}$ & $\mathbf{M e} \pm \mathbf{Q}$ & $\mathbf{M} \pm \mathbf{S}$ & $\mathbf{M e} \pm \mathbf{Q}$ & $\mathbf{M} \pm \mathbf{S}$ & $\mathbf{M e} \pm \mathbf{Q}$ & $\mathbf{M} \pm \mathbf{S}$ & $\mathbf{M e} \pm \mathbf{Q}$ & $\mathbf{M} \pm \mathbf{S}$ & $\mathbf{M e} \pm \mathbf{Q}$ & $\mathbf{M} \pm \mathbf{S}$ \\
\hline $\begin{array}{l}\text { Studia } \\
\text { stacjonarne } \\
\text { N=152 }\end{array}$ & $2,5 \pm 1,5$ & $2,8 \pm 1,6$ & $\mid \begin{array}{c}3,0 \pm 1,0 \\
*\end{array}$ & $\begin{array}{c}3,0 \pm 1,4 \\
*\end{array}$ & $3,0 \pm 1,0$ & $3,1 \pm 1,4$ & $\begin{array}{c}5,0 \pm 0,5 \\
*\end{array}$ & $\begin{array}{c}4,2 \pm 1,1 \\
*\end{array}$ & $4,0 \pm 0$, & $3,6 \pm 1,1$ & $4,0 \pm 1$ & $3,8 \pm 1,1$ \\
\hline $\begin{array}{l}\text { Studia } \\
\text { niestacjonarne } \\
\mathrm{N}=118\end{array}$ & $2,5 \pm 1,0$ & $2,5 \pm 1,3$ & $\begin{array}{c}4,0 \pm 0,5 \\
*\end{array}$ & $\mid \begin{array}{c}3,6 \pm 1,2 \\
*\end{array}$ & $3,0 \pm 1,0$ & $3,0 \pm 1,4$ & $\begin{array}{c}4,0 \pm 1,0 \\
*\end{array}$ & $\begin{array}{c}3,6 \pm 1,3 \\
*\end{array}$ & $4,0 \pm 1,0$ & $3,6 \pm 1,1$ & $4,0 \pm 1$ & $3,9 \pm 1,1$ \\
\hline Cala grupa & $3,0 \pm 1,5$ & $2,7 \pm 1,5$ & $\begin{array}{c}4,0 \pm 1,0 \\
*\end{array}$ & $\begin{array}{c}3,2 \pm 1,3 \\
*\end{array}$ & $3,0 \pm 1,0$ & $3,1 \pm 1,4$ & $\begin{array}{c}4,0 \pm 1,0 \\
*\end{array}$ & $\begin{array}{c}3,9 \pm 1,2 \\
*\end{array}$ & $4,0 \pm 0, s$ & $3,6 \pm 1,1$ & $4,0 \pm 1$ & $3,8 \pm 1,1$ \\
\hline
\end{tabular}

Poziom istotności dla testu ANOVA rang Kruskala-Wallisa * p $<0,05$.

Źródło: Opracowanie własne na podstawie wyników badań

Wyniki analiz pokazują, iż tryb studiów determinuje podejście do aktywności komunikacyjnej studentów. Portale społecznościowe są powszechnym medium wykorzystywanym do komunikacji interpersonalnej w grupach studentów stacjonarnych. Studenci niestacjonarni rzadziej wykorzystują media społecznościowe do wzajemnej interakcji.

W celu przedstawienia pełnej komunikacji interpersonalnej między badanymi grupami analizie poddano opinie studentów dotyczące komunikacji z nauczycielem.

Tabela 3. Rozkład częstości opinii studentów dotyczących kanalów komunikacyjnych w relacjach student-nauczyciel

\begin{tabular}{|c|c|c|c|c|c|c|c|c|c|c|c|c|c|}
\hline & \multirow{3}{*}{$\begin{array}{c}\text { Grupy } \\
\text { studenckie }\end{array}$} & \multicolumn{12}{|c|}{ Kanały komunikacyjne $\mathrm{w}$ relacji student-nauczyciel } \\
\hline & & \multicolumn{2}{|c|}{ czat } & \multicolumn{2}{|c|}{ e-mail } & \multicolumn{2}{|c|}{ fora dyskusyjne } & \multicolumn{2}{|c|}{$\begin{array}{c}\text { portale spolecz- } \\
\text { nościowe }\end{array}$} & \multicolumn{2}{|c|}{ telefonicznie } & \multicolumn{2}{|c|}{ na uczelni } \\
\hline & & $\mathbf{M e} \pm \mathbf{Q}$ & $\mathbf{M} \pm \mathbf{S}$ & $\mathbf{M e} \pm \mathbf{Q}$ & $\mathbf{M} \pm \mathbf{S}$ & $\mathbf{M e} \pm \mathbf{Q}$ & $\mathbf{M} \pm \mathbf{S}$ & $\mathbf{M e} \pm \mathbf{Q}$ & $\mathbf{M} \pm \mathbf{S}$ & $\mathbf{M e} \pm \mathbf{Q}$ & $\mathbf{M} \pm \mathbf{S}$ & $\mathbf{M e} \pm \mathbf{Q}$ & $\mathbf{M} \pm \mathbf{S}$ \\
\hline \multirow[b]{2}{*}{ 芯 } & $\begin{array}{l}\text { kobiety } \\
\mathrm{N}=154\end{array}$ & $5,0 \pm 1,0$ & $4,0 \pm 1,4$ & $3,0 \pm 1,0$ & $3,1 \pm 1,4$ & $5,0 \pm 1,0$ & $3,9 \pm 1,5$ & $5,0 \pm 1,0$ & $2,6 \pm 1,4$ & $2,0 \pm 1,0$ & $2,6 \pm 1,3$ & $4,0 \pm 1,0$ & $3,7 \pm 1,3$ \\
\hline & \begin{tabular}{|l} 
mężczyźni \\
N=116
\end{tabular} & $5,0 \pm 1,0$ & $4,1 \pm 1,4$ & $3,0 \pm 1,0$ & $3,1 \pm 1,2$ & $5,0 \pm 1,25$ & $3,0 \pm 1,5$ & $5,0 \pm 1,0$ & $2,6 \pm 1,5$ & $2,0 \pm 0,5$ & $2,6 \pm 1,2$ & $4,0 \pm 1,0$ & $3,7 \pm 1,3$ \\
\hline \multirow[b]{3}{*}{ 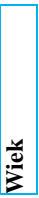 } & $\begin{array}{l}\text { do 20 lat } \\
\mathbf{N}=\mathbf{5 7}\end{array}$ & $\begin{array}{c}5,0 \pm 1,0 \\
* \\
\end{array}$ & $\begin{array}{c}4,5 \pm 1,0 \\
*\end{array}$ & $3,0 \pm 1,0$ & $3,1 \pm 1,3$ & $5,0 \pm 0,5$ & $4,4 \pm 1,2$ & $5,0 \pm 0,5$ & $4,3 \pm 1,2$ & $2,0 \pm 0,5$ & $2,5 \pm 1,1$ & $\begin{array}{c}3,0 \pm 1,0 \\
*\end{array}$ & $\begin{array}{c}3,0 \pm 1,4 \\
*\end{array}$ \\
\hline & $\begin{array}{l}\text { od } 21 \text { do } 25 \\
\text { lat } N=161\end{array}$ & $5,0 \pm 1,0$ & $3,9 \pm 1,5$ & $3,0 \pm 1,0$ & $3,1 \pm 1$, & $5,0 \pm 1,0$ & $3,9 \pm 1,6$ & $5,0 \pm 1,0$ & $4,1 \pm 1,5$ & $2,0 \pm 1,0$ & $2,6 \pm 1,3$ & $\begin{array}{c}4,0 \pm 0,5 \\
*\end{array}$ & $\begin{array}{c}3,9 \pm 1,3 \\
*\end{array}$ \\
\hline & \begin{tabular}{|l} 
od 26 lat \\
$\mathrm{N}=52$
\end{tabular} & $\begin{array}{l}5,0 \pm 1,( \\
*\end{array}$ & $\begin{array}{c}3,8 \pm 1,4 \\
*\end{array}$ & $3,0 \pm 1,0$ & $3,0 \pm 1,4$ & $5,0 \pm 1,5$ & $3,7 \pm 1,6$ & $5,0 \pm 1,5$ & $4,1 \pm 1,5$ & $2 \pm 0,75$ & $2,8 \pm 1,2$ & $\begin{array}{c}4,0 \pm 0,5 \\
*\end{array}$ & $\begin{array}{c}3,9 \pm 1,2 \\
*\end{array}$ \\
\hline \multicolumn{2}{|c|}{ Cala grupa } & $5,0 \pm 1,0$ & $4,0 \pm 1,4$ & $5,0 \pm 1,0$ & $3,1 \pm 1,3$ & $5,0 \pm 1,0$ & $4,0 \pm 1,5$ & $5,0 \pm 1,0$ & $4,1 \pm 1,4$ & $2 \pm 0,5$ & $2,6 \pm 1,2$ & $4,0 \pm 1,0$ & $3,7 \pm 1,3$ \\
\hline
\end{tabular}

Poziom istotności dla testu ANOVA rang Kruskala-Wallisa * $\mathrm{p}<0,05$.

Źródło: Opracowanie własne na podstawie wyników badań 
Analizując mediany i średnie $\mathrm{z}$ uwzględnieniem płci oraz wieku badanych, zauważa się kilka faktów. $Z$ danych empirycznych wynika, że komunikacja interpersonalna nie różni się istotnie statystycznie $\mathrm{w}$ grupach wyodrębnionych $\mathrm{z}$ uwagi na płeć badanych (Tabela 3). Natomiast istotne statystycznie różnice międzygrupowe wystąpiły z uwagi na wiek badanych w odniesieniu do komunikacji przez czat oraz w miejscu, na uczelni. Studenci w wieku do 20 lat częściej niż studenci w wieku od 26 lat wykorzystują czat do wirtualnego kontaktu z nauczycielem. Natomiast ze spotkań stacjonarnych na uczelni częściej korzystają studenci w wieku od 21 do 25 lat i wieku od 26 lat niż studenci najmłodsi, do 20 lat.

Ponadto zauważa się występowanie istotnych różnic międzygrupowych w odniesieniu do trybu studiów (Tabela 4).

Tabela 4. Rozkład częstości opinii studentów dotyczący komunikacji w relacjach student-nauczyciel

\begin{tabular}{|c|c|c|c|c|c|c|c|c|c|c|c|c|}
\hline \multirow{3}{*}{ Tryb studiów } & \multicolumn{12}{|c|}{ Kanały komunikacyjne w relacji student-nauczyciel } \\
\hline & \multicolumn{2}{|c|}{ czat } & \multicolumn{2}{|c|}{ e-mail } & \multicolumn{2}{|c|}{ fora dyskusyjne } & \multicolumn{2}{|c|}{$\begin{array}{c}\text { portale } \\
\text { spolecznościowe }\end{array}$} & \multicolumn{2}{|c|}{ telefonicznie } & \multicolumn{2}{|c|}{ na uczelni } \\
\hline & $\mathbf{M e} \pm \mathbf{Q}$ & $\mathbf{M} \pm \mathbf{S}$ & $\mathbf{M e} \pm \mathbf{Q}$ & $\mathbf{M} \pm \mathbf{S}$ & $\mathbf{M e} \pm \mathbf{Q}$ & $\mathbf{M} \pm \mathbf{S}$ & $\mathbf{M e} \pm \mathbf{Q}$ & $\mathbf{M} \pm \mathbf{S}$ & $\mathbf{M e} \pm \mathbf{Q}$ & $\mathbf{M} \pm \mathbf{S}$ & $\mathbf{M e} \pm \mathbf{Q}$ & $\mathbf{M} \pm \mathbf{S}$ \\
\hline $\begin{array}{l}\text { Studia } \\
\text { stacjonarne } \\
\text { N=152 }\end{array}$ & $5,0 \pm 1,0$ & $4,0 \pm 1,3$ & $\begin{array}{c}2,0 \pm 1,0 \\
*\end{array}$ & $\begin{array}{c}2,9 \pm 1,3 \\
*\end{array}$ & $5,0 \pm 1,0$ & $4,0 \pm 1,5$ & $\begin{array}{c}5,0 \pm 0,5 \\
*\end{array}$ & $\mid \begin{array}{c}4,3 \pm 1,3 \\
*\end{array}$ & $\begin{array}{c}2,0 \pm 1,0 \\
*\end{array}$ & $\begin{array}{c}2,8 \pm 1,3 \\
*\end{array}$ & $2,0 \pm 1,0$ & $3,9 \pm 1,3$ \\
\hline $\begin{array}{l}\text { Studia } \\
\text { niestacjonarne } \\
\mathrm{N}=118 \\
\end{array}$ & $5,0 \pm 1,0$ & $4,1 \pm 1,5$ & $\mid \begin{array}{c}4,0 \pm 1,0 \\
*\end{array}$ & $\begin{array}{c}3,2 \pm 1,3 \\
*\end{array}$ & $5,0 \pm 1,3$ & $4,0 \pm 1,6$ & $\begin{array}{c}5,0 \pm 1,0 \\
*\end{array}$ & $\begin{array}{c}4,0 \pm 1,5 \\
*\end{array}$ & $\begin{array}{c}2,0 \pm 0,5 \\
*\end{array}$ & $\begin{array}{c}2,5 \pm 1,2 \\
*\end{array}$ & $2,0 \pm 1,0$ & $3,6 \pm 1,3$ \\
\hline Cala grupa & $5,0 \pm 1,0$ & $4,0 \pm 1,4$ & $\begin{array}{c}3,0 \pm 1,0 \\
*\end{array}$ & $\begin{array}{c}3,1 \pm 1,3 \\
*\end{array}$ & $5,0 \pm 1,0$ & $4,0 \pm 1,5$ & $\begin{array}{c}5,0 \pm 1,0 \\
*\end{array}$ & $\begin{array}{c}4,1 \pm 1,4 \\
*\end{array}$ & $\begin{array}{c}2,0 \pm 0,5 \\
*\end{array}$ & $\begin{array}{c}2,6 \pm 1,2 \\
*\end{array}$ & $2,0 \pm 1,0$ & $3,7 \pm 1,4$ \\
\hline
\end{tabular}

Poziom istotności dla testu ANOVA rang Kruskala-Wallisa * p $<0,05$.

Źródło: Opracowanie własne na podstawie wyników badań

Według opinii studentów najczęstszą aktywnością studentów w relacjach z nauczycielem jest wirtualny kontakt $\mathrm{z}$ wykorzystywaniem mediów społecznościowych. Studenci studiów stacjonarnych częściej wykorzystują tę formę kontaktu interpersonalnego niż studenci studiów niestacjonarnych. Ponadto zauważa się, że studenci niestacjonarni częściej niż studenci stacjonarni korzystają z aktywności komunikacyjnej za pomocą poczty e-mail.

W odniesieniu do kontaktu z wykorzystaniem telefonii aktywność studentów jest niska, lecz występują istotne statystycznie różnice międzygrupowe. Średnia aktywność studentów stacjonarnych wskazuje na większe wykorzystanie kanału do aktywności komunikacyjnej niż w przypadku studentów stacjonarnych, którzy w niewielkim stopniu wykazują aktywność telefoniczną z nauczycielem.

Według wielu autorów (Zając 2009; Mokwa-Tanowska 2014; Sysło 2009, s. 25; Wach-Kąkolewicz 2007) w metodologii konstrukcji zajęć przez Internet najistotniejszy jest aktywny udział studentów w procesie nauczania - uczenia się. Według Wioletty Sołtysiak (Sołtysiak 2015, s. 56) dobór kanałów komunikacyjnych w e-learningu nie może być jednolity oraz przypadkowy. Sprzężenie zwrotne między uczestnikami procesu kształcenia powinno być podstawowym elementem zajęć dydaktycznych. 


\section{Podsumowanie}

E-learning wychodzi naprzeciw oczekiwaniom, procesom globalizacyjnym, przemianom cywilizacyjnym, które wymuszają rozwój osobisty i ciągłe doskonalenie, niezależnie od miejsca pobytu i dostępnego czasu.

Zauważa się, że budowa scenariuszy zajęć opartych na zasadach konstruktywistycznych sprzyja różnego rodzaju interakcji, aktywności podmiotu w czasie nauczania - uczenia się. Sprzyja osiąganiu zamierzonych celów edukacyjnych oraz wpływa na indywidualizację kształcenia.

Według Dereka Rowntree (Rowntree 1997) to nauczyciel jest motorem tworzenia sytuacji sprzyjającej osiąganiu wysokich efektów kształcenia, pobudzania do aktywności edukacyjnej. Od jego zaangażowania w proces kształcenia, stymulowania uczących zależy, w jakim stopniu zostaną osiągnięte cele edukacyjne oraz satysfakcja z nauczania - uczenia się.

Realizacja procesu e-learningu zobowiązuje nauczyciela do tworzenia przyjaznego środowiska wirtualnego, wyzwalającego aktywności studentów, gdzie uczący będą chcieć wracać, nawiązywać relacje interpersonalne, akty komunikacyjne. Jak zauważają Dorota Jelonek, Adam Nowicki i Leszek Ziora (Jelonek, Nowicki, Ziora 2014, s. 155), kluczem do postępów w nauce jest interakcja z aktorami procesu kształcenia. W tym kontekście, w odniesieniu do wyników badań, proponuje się implikacje dla praktyków edukacyjnych oraz metodologów, wprowadzenie instrumentów komunikacyjnych wyzwalających największe aktywności w relacjach student-nauczyciel:

- forów dyskusyjnych $-72,5 \%$,

- portali społecznościowych $-71,5 \%$,

- tradycyjnie, na uczelni - $69,6 \%$,

- czatu $67,7 \%$.

Natomiast w samokształceniu studentów postuluje się zachęcać do współpracy poprzez:

- portale społecznościowe $-73,0 \%$,

- kontakt telefoniczny $-57,4 \%$,

- tradycyjnie, na uczelni - 55,2\%,

- e-mail 52,5\%.

Wymienione aktywności były najczęściej wymienianymi przez studentów aktywnościami komunikacyjnymi stosowanymi w ramach przedmiotów realizowanych w formie e-learningu.

Ponadto zauważa się występowanie różnic międzygrupowych w podejściu do poszczególnych aktywności komunikacyjnych. Wyróżniono te, które uzyskały najwyższe częstości aktywności komunikacyjnych:

- komunikacja za pomocą instrumentów portali społecznościowych w zależności od trybu studiów (stacjonarne i niestacjonarne) $\mathrm{M}_{\text {stacjon. }}=5,0 \mathrm{M}_{\text {niestacjon. }}=4,0$;

- komunikacja za pomocą instrumentów portali społecznościowych w zależności od wieku badanych $\mathrm{Me}_{\text {do } 20 \text { lat }}=4,2 \mathrm{Me}_{\text {od } 26 \text { lat }}=3,0$;

- komunikacja za pomocą czatu w zależności od wieku badanych $\mathrm{Me}_{\mathrm{do}} 20$ lat $=4,0$ $\mathrm{Me}_{\text {od } 21 \text { lat do } 25 \mathrm{i} \text { od } 26 \text { lat }}=3,0$. 
Zauważa się, iż social media poprzez swój „społecznościowy” charakter, umożliwiający współtworzenie i rozpowszechnianie oraz umożliwianie jednostkom wypowiadanie się i sprawianie, że ich aktywności są widoczne, stały się nieodłącznym narzędziem komunikacji we współczesnym świecie. Wyniki badań są potwierdzeniem przypuszczeń, że im młodsza społeczność, tym aktywność wirtualna jest większa i dlatego budując scenariusze zajęć, należy uwzględniać różne formy aktywności wśród młodzieży, ze szczególnym uwzględnianiem potencjału social mediów.

Nasuwają się pytania, czy wymienione aktywności reprezentują tylko edukacyjne akty komunikacyjne, czy inne tematycznie obszary, takie jak: towarzyskospołeczny, organizacyjny czy techniczny. Pytania pozostają do dalszych rozważań. Ponadto autorka zaproponowała dwie relacje komunikowania: student-nauczyciel, student-student, w odwołaniu do opinii studentów. Wydaje się to interesujące aplikacyjnie, istnieje możliwość przeprowadzenia badań w interakcji student-grupa oraz poznanie opinii nauczycieli na temat różnych aktywności komunikacyjnych.

\section{Literatura}

1. Bołtuć P. (2011), Konstruktywizm w edukacji oraz jego krytyka, „E-mentor”, nr 4(41).

2. Carr D.K., Hard K.J., Trahant W.J. (1998), Zarzadzanie procesem zmian, Wydawnictwo Naukowe PWN, Warszawa.

3. Conrad R.M., Donaldson J.A. (2004), Engaging the Online Learner, Activities and Resources for Creative Instruction, Jossey-Bass, San Francisco.

4. Hackman J.R. (2002), Leading Teams: Setting the Stage for Great Performances, Harvard Business School Press, Boston.

5. Jelonek D. (2014), Personalizacja jako determinanta sukcesu współpracy z klientem w przestrzeni internetowej, „Prace Naukowe WWSZiP”, nr 27(2).

6. Jelonek D., Nowicki A., Ziora L. (2014), The Application of E-Learning in the Didactic Process at the Faculty of Management in Czestochowa University of Technology: Organization, Tools, Model, [w:] Cohen E., Boyd E. (eds.), Proceedings of Informing Science \& IT Education Conference (InSITE), Published by The Informing Science Institute Santa Rosa, California.

7. Jędryczkowski J. (2012), Indywidualizacja procesu uczeniu się a formy komunikacji w e-learningowym module edukacyjnym, http://www.uz.zgora.pl/ jjedrycz/publikacje/038/ Indywidualizacja\%202012_hdom.pdf (dostęp: 14.08.2015).

8. Jędryczkowski J. (2013), Motywacja w procesie kształcenia na odległość, „General and Professional Education", nr 1.

9. Mokwa-Tarnowska I. (2014), Struktury wsparcia a efektywność ksztatcenia $w$ środowisku e-learningowym, „E-mentor”, $\mathrm{nr}$ 2(54).

10. Pyszka A. (2015), Modele i determinanty efektywności zespołu, „Studia Ekonomiczne. Zeszyty Naukowe Uniwersytetu Ekonomicznego w Katowicach", nr 230.

11. Rowntree D. (1997), Making Materials-Based Learning Work, Kogan Page, London.

12. Sołtysiak W. (2015), Proces konstruowania wiedzy $w$ e-learningu akademickim, [w:] Perechuda K., Chomiak-Orsa I. (red.), Wiedza i informacja $w$ akceleracji biznesu, Wydawnictwo Wydziału Zarządzania Politechniki Częstochowskiej, Częstochowa.

13. Sysło M.M. (2009), E-learning w szkole, „E-mentor”, nr 1(28).

14. Wach-Kąkolewicz A. (2007), Aktywność komunikacyjna studentów i nauczyciela w kształceniu przez Internet, „E-mentor”, $\mathrm{nr} 5(22)$.

15. Zając M. (2009), Model aktywności w kursach on-line, czyli efektywnie angażować studentów, „E-mentor”, nr 4(31). 


\title{
DETERMINANTS OF STUDENTS' ACTIVITY \\ IN THE CONTEXT OF E-LEARNING
}

\begin{abstract}
Purpose of the paper is to identify determinants of students' activity in e-learning. While striving for realization of such an objective, undertaken activities have been presented on the background of selected communication models, presented in literature of the subject, as well as performer empirical studies or own research. In this context the situation was identified in the scope of including the e-learning process into the interpersonal activity of the education participants and their impact on teaching-learning effects. It is observed that the development process for classes scenarios should consider various communication interactions of the education process actors, which exert positive influence on the e-learning process.
\end{abstract}

Keywords: interpersonal activity, e-learning, communication channels, interpersonal activity models 